a steel frame outside the Observatory, will run for about $2 \frac{3}{4}$ hours without re-winding. It is controlled electrically by a seconds pendulum mounted in the vestibule. Slow and rapid motions in R.A. are provided by means of a specially geared electric motor, working on the driving-worm independently of the clock.

"In recent years several American and continental observatories have added small-scale photographic instruments to their equipments, but it is believed that the Mond equatorial is the first of its kind to be erected in Great Britain.

"The uses to which the instrument can or will be put include the photography of meteors, comets, and large nebulosities of the galactic type. In addition, the search for new minor planets, comets, variable stars, and novæ can be undertaken with such an apparatus with a greater hope of success than where an instrument of greater power but smaller field of view is used. Even unsystematic work with this battery of cameras may be of considerable ultimate value."

At the opening ceremony, Sir Richard Gregory, chairman of the Council of the Observatory, said he hoped that the wide and intelligent public interest now shown in astronomical subjects would lead to increased support for the Observatory, in which valuable work in astronomy is being carried on with instruments and funds provided by private donors, and without the aid or control of State or other official institutions. Private benefactions have provided the United States with the finest observatories in the world, with the result that we owe to American astronomers some of the most important observations made in recent years in solar and stellar astronomy, particularly in the field of astronomical physics. It is perhaps too much to expect similar munificent support for astronomical research in Great Britain, but it ought not to be too much to hope that an observatory like that on Salcombe Hill, in which many notable contributions to progressive knowledge have been made, should be placed in such a financial position that the maintenance of its activities will be ensured.

In the course of his remarks, Sir Frank Dyson said: "It is now ten years since I had the honour of unveiling here the tablet to Sir Norman Lockyer. There can be no doubt that his spirit pervades the Observatory. Constant observation seems to be the rule, and there are more fine nights here than we have at Greenwich. Dr. Lockyer produces for us with regularity valuable papers on stars with bright hydrogen lines. $\mathrm{He}$ is making constant observations of stars in which the intensity of the components of these lines varies. A star in Camelopardalis, Bradley 448, he observed through the entire cycle $1925-30$ of its variability. $\mathrm{He}$ has also discussed $\varphi$ Persei and a number of other stars, and has discovered a number of new stars with bright hydrogen lines. Mr. Edwards is repeatedly bringing out spectroscopic parallaxes of early type stars. The influence of the Observatory is felt as far away as Canberra, where Mr. Rimmer is carrying on valiantly under difficult financial conditions. I am quite sure Sir Norman would have been delighted to see how the work, in which he was so greatly interested, is being developed.'

Dr. R. G. Atkin, director of the Lick Observatory, said that he always read with great interest the papers describing the spectroscopic and other observations and results achieved at the Observatory, and he congratulated the Council upon the addition of a most useful instrument to its equipment. Dr. Mond, in his reply, referred to his long association with Sir Norman Lockyer and Dr. Lockyer, and said that he regarded the new instrument as an astronomical 'robot' which would faithfully record celestial appearances and events over wide fields of view while the staff of the Observatory was carrying on the routine spectroscopic work on individual stars; and the photographs thus obtained would be of permanent value for astronomical reference and discovery.

\title{
International Committee of the History of Science
}

$\mathrm{T}^{\mathrm{H}}$ HE fourth annual conference of the Comité International d'Histoire des Sciences was held in Paris on May 13-16, under the presidency of Prof. Karl Sudhoff. Among those present were Mme. Hélène Metzger, Prof. P. Diepgen, Prof. F. Faddegon, Dr. E. J. Holmyard, Prof. Louis Massignon, Prof. Aldo Mieli (permanent secretary), Prof. E. Mittwoch, Prof. A. Reymond, and Prof. D'Arcy W. Thompson. The meetings were held at the Centre international de Synthese (12 Rue Colbert), and, apart from formal business, were devoted entirely to the history of the sciences in medieval Islam. The president, Prof. Sudhoff, read a paper on Constantine, the first to transmit Muslim science to the West, and described the part played in this transmission by Maurus and Urso, two early schoolmen of Salerno. Prof. Massignon, in a brilliant discourse, pointed out the contrast between Greek and Muslim conceptions of numbers, and suggested the importance of Manichæan ideas in early arithmology.

The present state of research into Arabic mathematics, astronomy, and physics was fully described in a report by Prof. Faddegon, and similar reports on geography, cartography, and medicine were presented by Profs. Ferrand, Renaud, and Mittwoch. The chairman of the sub-committee for Arabic studies, Prof. Julius Ruska, was unfortunately not able to attend the conference, but his report on Arabic alchemy was read by Prof. Diepgen. Though much has been done in recent years, particularly on the Jabir problem, the Emerald Table of Hermes, and the Turba
Philosophorum, it was evident from Prof. Ruska's report that the full elucidation of Muslim alchemical ideas and practice will require many years of intensive effort. In the course of the discussion, it was suggested that an urgent need is the detailed investigation of the numerous works of Aidamir al-Jildaki, while a catalogue of Arabic alchemical manuscripts in Spain is greatly to be desired. The possibility was mooted of establishing a central card index of Arabic technical and scientific terms, to supplement the meagre information on this subject contained in the standard dictionaries of Lane, Dozy, etc. A collateral index of alchemical and other signs was also considered desirable.

A further problem that the Comité regards as worthy of close attention is the assessment of the influence upon Muslim scientific thought of the doctrines of Gnosticism, Neoplatonism, and Manichæism; the latter in particular, according to Prof. Massignon, has left very distinct traces in Muslim alchemical theory. The question of the systems of transcription of Arabic words gave rise to considerable difference of opinion, but it was generally felt that no single system is likely to attain universal adoption, however desirable such uniformity may be.

On Saturday, May 14, members of the conference were given a delightful reception at the Sorbonne, by the Institut d'études islamiques and the Institut d'histoire des sciences. The next annual meetings of the Comité will be held at Warsaw (1933) and Berlin (1934). 